\title{
Emergence, longevity and fecundity of Trissolcus basalis and Telenomus podisi after cold storage in the pupal stage
}

Luís Amilton Foerster ${ }^{(1)}$, Augusta Karkow Doetzer ${ }^{(1)}$ and Letícia Cunha Ferreira de Castro ${ }^{(1)}$

(1)Universidade Federal do Paraná, Dep. de Zoologia, Caixa Postal 19020, CEP 81531-990 Curitiba, PR. E-mail: foerster@ufpr.br

Abstract - Pupae of Trissolcus basalis (Wollaston) and Telenomus podisi Ashmead (Hymenoptera: Scelionidae) were stored at $12^{\circ} \mathrm{C}$ and $15^{\circ} \mathrm{C}$ for $120-210$ days, after different periods of parasitism at $18^{\circ} \mathrm{C}$ in order to evaluate adult emergence, longevity and ovipositional capacity. There was no emergence of adults at $12^{\circ} \mathrm{C}$. The rate of emergence of parasitoids transferred to $15^{\circ} \mathrm{C}$ at the beginning of the pupal stage was $1.5 \%$ and $26.3 \%$, for T. basalis and T. podisi respectively, whereas those parasitoids transferred one day before the expected date of emergence at $18^{\circ} \mathrm{C}$ showed $86.4 \%$ of emergence for T. basalis and $59.9 \%$ for T. podisi. Mean adult longevity was also significantly lower when pupae were transferred to $15^{\circ} \mathrm{C}$ at the beginning of the pupal stage. Females emerged after storage and maintained for 120 to 210 days at $15^{\circ} \mathrm{C}$ parasitized host eggs after transference to $25^{\circ} \mathrm{C}$; however, fecundity of $T$. podisi was reduced in about $80 \%$ after cold storage.

Index terms: Insecta, hibernation, egg parasitoids, biological control.

\section{Emergência, longevidade e fecundidade de Trissolcus basalise Telenomus podisiapós estocagem no estágio pupal}

Resumo - Pupas de Trissolcus basalis (Wollaston) e Telenomus podisi Ashmead (Hymenoptera: Scelionidae) armazenadas a $12^{\circ} \mathrm{C} \mathrm{e} 15^{\circ} \mathrm{C}$ por 120 a 210 dias, após diferentes períodos de parasitismo a $18^{\circ} \mathrm{C}$, foram avaliadas quanto à emergência, longevidade e capacidade de parasitismo dos adultos. Não houve emergência de adultos a $12^{\circ} \mathrm{C}$. Os índices de emergência de parasitóides transferidos a $15^{\circ} \mathrm{C}$ no início do estágio pupal foram $1,5 \%$ e $26,3 \%$, em $T$. basalis e $T$. podisi, respectivamente, enquanto os transferidos um dia antes da data prevista para a emergência dos adultos a $18^{\circ} \mathrm{C}$ apresentaram índices de emergência de $86,4 \%$ em $T$. basalis e $59,9 \%$ em T. podisi. De forma semelhante, a longevidade média dos adultos foi significativamente menor quando a transferência para $15^{\circ} \mathrm{C}$ foi realizada no início do estágio pupal. Fêmeas emergidas após estocagem das pupas e mantidas por 120 a 210 dias a $15^{\circ} \mathrm{C}$ parasitaram ovos hospedeiros após transferência para $25^{\circ} \mathrm{C}$; no entanto, a fecundidade de T. podisi foi reduzida em cerca de $80 \%$ quando mantida em baixa temperatura.

Termos para indexação: Insecta, hibernação, parasitóides de ovos, controle biológico.

\section{Introduction}

Several egg parasitoids of subtropical and temperate regions overwinter in a hibernation state (Boivin, 1994), which can determinate their population dynamics, geographic distribution and potential as biological control agents (Mansingh, 1971; Boivin, 1994). The developmental stage susceptible to hibernation differs between species; however, most egg parasitoids hibernate as larvae or pupae within the host egg (Boivin, 1994).

Low temperatures and short photoperiods can induce hibernation on egg parasitoids and this procedure is useful to optimize mass-production of these natural enemies and to improve synchronization between the pest and the parasitoid (Boivin, 1994).

Most research on cold storage of egg parasitoids has been conducted on Trichogramma species (Stinner et al., 1974; Curl \& Burbutis, 1977; Jalali \& Singh, 1992; Laing \& Corrigan, 1995), Ooencyrtus ennomus Yoshimoto (Encyrtidae) (Anderson \& Kaya, 1974, 1975) and Encarsia formosa Gahan (Aphelinidae) (Lacey et al., 1999).

The storage of Telenomus remus Nixon in the pupal stage at $10^{\circ} \mathrm{C}$ for seven days did not influence parasitoid survival (Gautam, 1986). Storage of Trissolcus basalis 
(Wollaston) and Telenomus podisi Ashmead eggs and larvae was unsuitable for parasitoid emergence. However, adults of $T$. basalis and $T$. podisi that emerged at $15^{\circ} \mathrm{C}$ when pupae were stored one day before the predicted date for emergence survived for about five months at the low temperature (Foerster \& Nakama, 2002).

The objective of this work was to determine the effect of pupae storage at $12^{\circ} \mathrm{C}$ and $15^{\circ} \mathrm{C}$ after different periods of parasitism on adult emergence, longevity and fecundity of Trissolcus basalis and Telenomus podisi.

\section{Material and Methods}

Stink bugs Nezara viridula (L.) and Euschistus heros (Fabr.) (Heteroptera: Pentatomidae) were used as hosts for Trissolcus basalis and Telenomus podisi respectively. Specimens used in this work were obtained from the Laboratory of Integrated Control of Insects at the Universidade Federal do Paraná, Brazil.

Egg masses with 40 eggs of $N$. viridula and $E$. heros were exposed respectively to five females of $T$. basalis and $T$. podisi, at $18 \pm 0,5^{\circ} \mathrm{C}$ (12L: $\left.12 \mathrm{D}\right)$, during 48 hours. After this period, the parasitoids were discarded and the parasitized eggs remained on moistened filter paper. At different dates after parasitism, these eggs were transferred from $18^{\circ} \mathrm{C}$ to either $15 \pm 0,5^{\circ} \mathrm{C}$ or $12 \pm 0,5^{\circ} \mathrm{C}$ (10L:14D) to evaluate adult emergence. Storage at $12^{\circ} \mathrm{C}$ was made 15,20 and 25 days after parasitism; at $15^{\circ} \mathrm{C}$ both parasitoids were stored 15, 20, 25, 26, 28 and 30 days after parasitism and for T. podisi, the parasitoids were also stored 33 days after parasitism, because this species has lower developmental rate than T. basalis. Emergence rate, developmental time and progeny sex ratio were recorded in each treatment.

Adults were fed with honey and maintained in glass tubes $(17 \mathrm{x} 2 \mathrm{~cm})$ partially covered with black paper; previous results showed that this procedure increases their longevity (Doetzer, 2003). Mortality of T. basalis and $T$. podisi was daily recorded

The effect of pupal storage at $15^{\circ} \mathrm{C}$ on the fecundity of parasitoids emerged was evaluated. Females of T. basalis and T. podisi emerged after storage one day before the predicted date for emergence were maintained at $15^{\circ} \mathrm{C}$ between 120 and 210 days and then transferred to $25^{\circ} \mathrm{C}$ at 30 days intervals. Ten females of each species were individually exposed to 50 E. heros eggs for 24 hours one day after transference to $25^{\circ} \mathrm{C}$. Parasitoids were discarded after this period and the eggs were maintained on moistened filter paper. The number of parasitized eggs per female and progeny sex ratio was recorded. Results were analyzed in relation to a control treatment, conducted with females developed continuously at $25^{\circ} \mathrm{C}$ and exposed to host eggs one day after emergence.

Data were submitted to analysis of variance and means compared by Tukey's test $(\mathrm{p}<0.05)$. Comparisons between species were done by t test $(p<0.05)$. The relationships between storage age and emergence rate, developmental rate, progeny sex ratio and adult longevity were evaluated by linear regression analysis.

\section{Results and Discussion}

Adults failed to emerge when T. basalis and T. podisi pupae were transferred from $18^{\circ} \mathrm{C}$ to $12^{\circ} \mathrm{C}$ at any of the pupal ages evaluated, showing that storage at this temperature is lethal to the parasitoids in the pupal stage.

Parasitoids stored at $15^{\circ} \mathrm{C}$ in the pupal stage continued to develop and emerged at this temperature. Emergence of $T$. basalis occurred in all treatments at $15^{\circ} \mathrm{C}$, whereas no adults of $T$. podisi emerged when their pupae were stored 15 days after parasitism (Table 1). Pupal age at storage significantly influenced adult emergence (T. basalis: $\mathrm{y}=-84.06+5.89 \mathrm{x}, \mathrm{R}^{2}=0.80, \mathrm{p}<0.05$; T. podisi: $\left.\mathrm{y}=-38.23+3.05 \mathrm{x}, \mathrm{R}^{2}=0.59, \mathrm{p}<0.05\right)$ and developmental rate of the parasitoids (T. basalis: $\mathrm{y}=89.04-1.92 \mathrm{x}, \mathrm{R}^{2}=0.77, \mathrm{p}<0.05 ;$ T. podisi: $\mathrm{y}=85.29$ $\left.-1.47 \mathrm{x}, \mathrm{R}^{2}=0.60, \mathrm{p}<0.05\right)$ (Figure 1).

Cold storage of pupae did not affect the sex ratio of the parasitoids, as also found for T. remus (Gautam, 1986). Progeny sex ratio of T. basalis ranged from 0.67 to 0.95 and for $T$. podisi, ranged from 0.71 to 0.80 (Table 1). Relationships between the age of the stored pupae and progeny sex ratio were not detected (T. basalis: $\mathrm{y}=96.23-0.59 \mathrm{x}, \mathrm{R}^{2}=0.04, \mathrm{p}>0.05$; T. podisi: $\mathrm{y}=75.98+0.01 \mathrm{x}, \mathrm{R}^{2}=0.01, \mathrm{p}>0.05$ ) (Figure 1).

Adult parasitoids that emerged after pupal storage at $15^{\circ} \mathrm{C}$ hibernated with a drastic reduction in mobility and feeding (Mansingh, 1971). Pupal age at storage affected adult longevity for both species $(\mathrm{p}<0.05)(T$. basalis, males: $\mathrm{y}=5.38+6.34 \mathrm{x}, \mathrm{R}^{2}=0.11$ and females, $\mathrm{y}=-263.56+18.23 \mathrm{x} ; \mathrm{R}^{2}=0.42 ; T$. podisi, males: $\mathrm{y}=-78.09+6.34 \mathrm{x}, \mathrm{R}^{2}=0.32$ and females, $\mathrm{y}=-93.61+$ $10.29 x, R^{2}=0.25$ ) (Figure 2). Highest longevity was verified when parasitoids were stored at $15^{\circ} \mathrm{C}$ one day before the predicted date of emergence (nine and eight 
months, for T. basalis and T. podisi, respectively) and decreased when the pupae were stored at the beginning of the stage. Females survived longer than males and T. basalis longevity was higher than $T$. podisi (Table 2 )
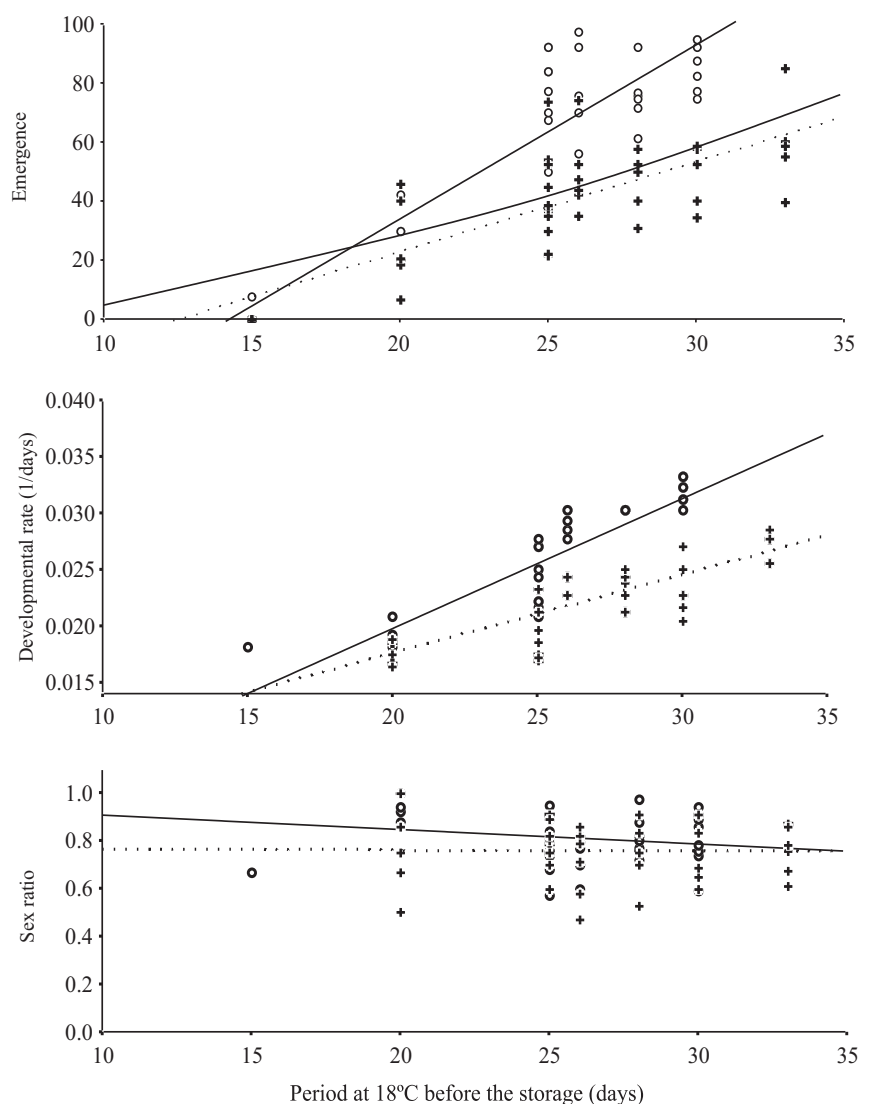

Figure 1. Relationship between the period at $18^{\circ} \mathrm{C}$ before the storage and the percentage of emerged adults, developmental rate and sex ratio of Trissolcus basalis (- - - ) and Telenomu podisi $(-+-)$ stored at $15^{\circ} \mathrm{C}$ at different dates after parasitism.
Parasitoids stored at earlier stages of pupal development spent more energy to complete their development and, therefore, their longevity was shorter. Similarly, the longevity of females of $T$. oenone that emerged at $15^{\circ} \mathrm{C}$ was lower than of those that emerged at $17.5^{\circ} \mathrm{C}$ (James \& Warren, 1991). Adults of T. basalis emerging at $15^{\circ} \mathrm{C}$ were small, inactive and survived less than one day (Orr et al., 1985).

Foerster \& Nakama (2002) found that the mean longevity of $T$. basalis and $T$. podisi transferred from $25^{\circ} \mathrm{C}$ to $15^{\circ} \mathrm{C}$ one day before the predicted date for emergence was of about five months; this value is lower than the results obtained in this work. Longevity of $T$. basalis and $T$. podisi at $15^{\circ} \mathrm{C}$ was also higher than that of other Scelionidae species such as Ceratobaeus masneri Austin (Austin, 1984) and Trissolcus oenone (Dodd) (James \& Warren, 1991).

Females of $T$. basalis and $T$. podisi emerging after pupal storage one day before the predicted date for emergence and maintained at $15^{\circ} \mathrm{C}$ for 120 to 210 days, parasitized host eggs (Figure 3). Fecundity of $T$. basalis decreased as storage period increased from 120 to 180 days; however, after storage for 210 days, fecundity values increased as those recorded for females reared at $25^{\circ} \mathrm{C}$ (Figure 3 ). This increased fecundity after storage for seven months could not be explained, which shows the need for additional research in order to fully understand the reproductive dynamics of this species. Females of $T$. podisi were more affected by adult maintenance at $15^{\circ} \mathrm{C}$, than $T$. basalis. The fecundity of $T$. podisi after storage at $15^{\circ} \mathrm{C}$ was lower than that of females reared at $25^{\circ} \mathrm{C}$ and the mean number of parasitized eggs decreased as the storage period increased, ranging from 0.0 to 6.4 parasitized eggs (Figure 3). Progeny sex ratio ranged from 0.87 to 0.92 for T. basalis, and from 0.34 to 0.69 for $T$. podisi and was

Table 1. Emergence (\%), developmental time (days) and progeny sex ratio (number of females/total number of emerged adults) of Trissolcus basalis and Telenomus podisi stored at $15^{\circ} \mathrm{C}$ in different dates after parasitism at $18^{\circ} \mathrm{C}^{(1)}$.

\begin{tabular}{|c|c|c|c|c|c|c|}
\hline \multirow{2}{*}{$\begin{array}{l}\text { Period at } 18^{\circ} \mathrm{C} \text { before } \\
\text { the storage (days) }\end{array}$} & \multicolumn{2}{|c|}{ Emergence } & \multicolumn{2}{|c|}{ Developmental time } & \multicolumn{2}{|c|}{ Sex ratio } \\
\hline & T. basalis & T. podisi & T. basalis & T. podisi & T. basalis & T. podisi \\
\hline 15 & $1.5 \pm 1.49 \mathrm{c}$ & $0.0 \pm 0.00$ & $55.0 \pm 0.00 \mathrm{a}$ & - & $0.67 \pm 0.00 \mathrm{~b}$ & - \\
\hline 20 & $28.5 \pm 4.15 \mathrm{bA}$ & $26.3 \pm 7.23 \mathrm{bA}$ & $52.2 \pm 1.16 \mathrm{aA}$ & $57.0 \pm 1.58 \mathrm{aB}$ & $0.95 \pm 0.02 \mathrm{aA}$ & $0.80 \pm 0.08 \mathrm{aA}$ \\
\hline 25 & $70.7 \pm 6.02 \mathrm{aA}$ & $41.0 \pm 5.06 \mathrm{aB}$ & $42.3 \pm 1.48 \mathrm{bA}$ & $49.8 \pm 2.15 \mathrm{bB}$ & $0.80 \pm 0.04 \mathrm{abA}$ & $0.80 \pm 0.03 \mathrm{aA}$ \\
\hline 26 & $78.5 \pm 7.49 \mathrm{aA}$ & $49.3 \pm 5.56 \mathrm{aB}$ & $34.2 \pm 0.58 \mathrm{cA}$ & $42.5 \pm 0.67 \mathrm{cB}$ & $0.74 \pm 0.04 \mathrm{bA}$ & $0.71 \pm 0.06 \mathrm{aA}$ \\
\hline 28 & $75.5 \pm 4.11 \mathrm{aA}$ & $46.8 \pm 3.96 \mathrm{aB}$ & $35.7 \pm 1.67 \mathrm{cA}$ & $43.5 \pm 1.23 \mathrm{cB}$ & $0.83 \pm 0.04 \mathrm{abA}$ & $0.78 \pm 0.06 \mathrm{aA}$ \\
\hline 30 & $86.4 \pm 3.12 \mathrm{aA}$ & $46.3 \pm 5.09 \mathrm{aB}$ & $31.3 \pm 0.42 \mathrm{cA}$ & $43.3 \pm 1.75 \mathrm{cB}$ & $0.79 \pm 0.04 \mathrm{abA}$ & $0.77 \pm 0.06 \mathrm{aA}$ \\
\hline 33 & - & $59.9 \pm 5.97 \mathrm{a}$ & - & $36.8 \pm 0.70 \mathrm{c}$ & - & $0.76 \pm 0.04 \mathrm{a}$ \\
\hline
\end{tabular}



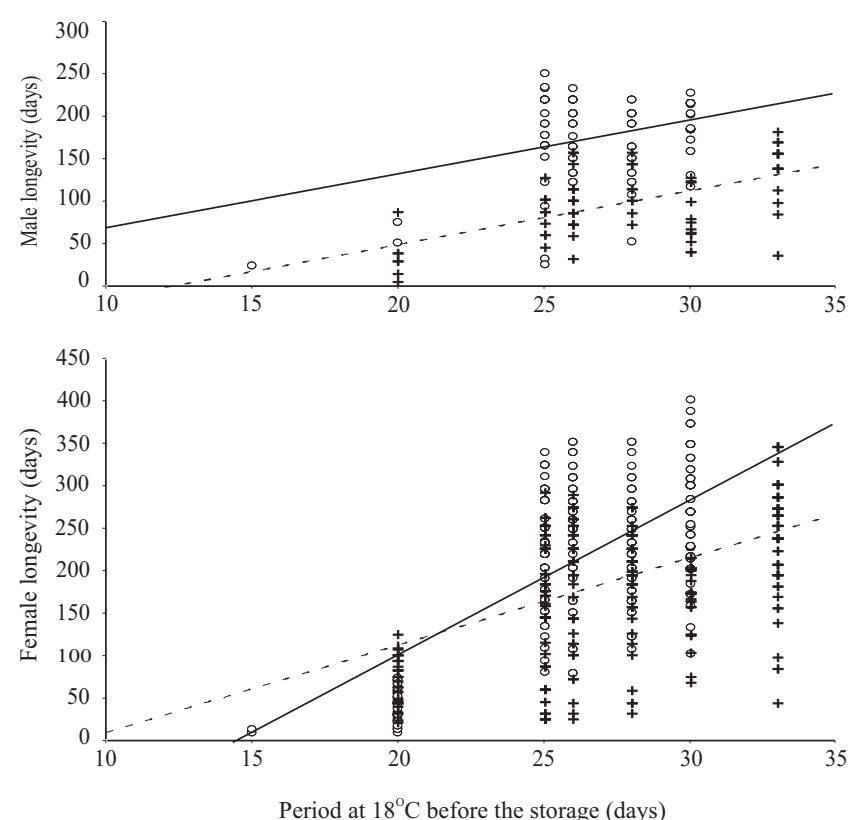

Figure 2. Relationship between the period at $18^{\circ} \mathrm{C}$ before the storage and the adult longevity of Trissolcus basalis (- - - ) and Telenomus podisi (-+-) emerged and maintained at $15^{\circ} \mathrm{C}$ after storage at different dates after parasitism.

Table 2. Longevity (days) of Trissolcus basalis and Telenomus podisi emerged at $15^{\circ} \mathrm{C}$ after pupal storage in different dates after parasitism at $18^{\circ} \mathrm{C}^{(1)}$.

\begin{tabular}{|c|c|c|c|c|}
\hline \multirow{2}{*}{$\begin{array}{l}\text { Period before } \\
\text { storage (days) }\end{array}$} & \multicolumn{4}{|c|}{ T. basalis } \\
\hline & Males & Range & Females & Range \\
\hline 15 & $24.0(1)$ & & $12.0 \pm 2.00(2)^{3}$ & $10-14$ \\
\hline 20 & $75.3 \pm 14.14(3)^{3}$ & $51-100$ & $42.3 \pm 3.21 \mathrm{c}(35)$ & $10-74$ \\
\hline 25 & $175.8 \pm 11.03 a(26)$ & $25-250$ & $231.6 \pm 6.61 \mathrm{~b}(76)$ & $81-340$ \\
\hline 26 & $186.0 \pm 6.65 a(28)$ & $122-233$ & $249.2 \pm 8.34 \mathrm{ab}(59)$ & $80-352$ \\
\hline 28 & $166.7 \pm 8.39 \mathrm{a}(24)$ & $52-219$ & $224.7 \pm 6.11 \mathrm{~b}(83)$ & $108-352$ \\
\hline 30 & $188.7 \pm 6.34 \mathrm{a}(21)$ & $117-228$ & $266.1 \pm 6.77 a(81)$ & $103-401$ \\
\hline 33 & & - & & - \\
\hline \multirow[t]{3}{*}{ Mean } & $175.4 \mathrm{~B}$ & & $220.3 \mathrm{~A}$ & \\
\hline & \multicolumn{4}{|c|}{ T. podisi } \\
\hline & Males & Range & Females & Range \\
\hline 15 & & & & \\
\hline 20 & $35.1 \pm 9.99 \mathrm{c}(17)$ & $5-88$ & $71.5 \pm 5.65 \mathrm{~d}(28)$ & $22-126$ \\
\hline 25 & $82.9 \pm 8.61 \mathrm{abc}(19)$ & $46-128$ & $170.0 \pm 9.56 \mathrm{c}(65)$ & $26-293$ \\
\hline 26 & $97.8 \pm 8.33 \mathrm{abc}$ & $32-158$ & $204.0 \pm 8.53 \mathrm{~b}(60)$ & $25-290$ \\
\hline 28 & $118.1 \pm 9.00 \mathrm{ab}(20)$ & $73-158$ & $203.4 \pm 6.59 \mathrm{~b}(68)$ & $32-275$ \\
\hline 30 & $79.7 \pm 8.41 \mathrm{bc}(19)$ & $41-124$ & $169.4 \pm 9.01 \mathrm{bc}($ & $69-216$ \\
\hline 33 & $136.9 \pm 9.32 \mathrm{a}(16)$ & $37-182$ & $240.6 \pm 8.19 \mathrm{a}(63)$ & $44-346$ \\
\hline Mean & $98.4 \mathrm{C}$ & & $189.2 \mathrm{~B}$ & \\
\hline
\end{tabular}

Pesq. agropec. bras., Brasília, v.39, n.9, p.841-845, set. 2004

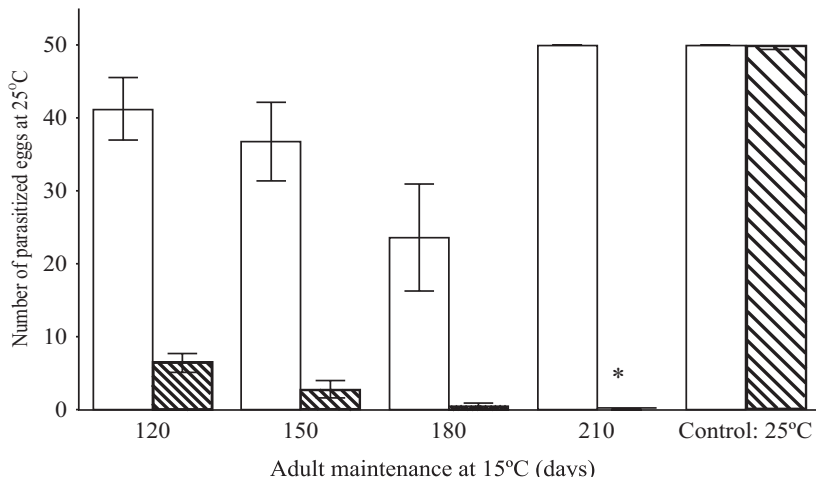

Figure 3. Number of parasitized eggs (means \pm standard error) at $25^{\circ} \mathrm{C}$ by Trissolcus basalis $(\square)$ and Telenomus podisi $(\mathbb{B})$ emerged after pupae storage one day before the predicted date for emergence and maintained as adults at $15^{\circ} \mathrm{C}$ for 120 to 210 days (50 eggs offered to one female during 24 hours; *eggs were not parasitized).

not influenced by adult maintenance at $15^{\circ} \mathrm{C}$. Several studies have shown the impact of cold storage on the fecundity of egg parasitoids; Flanders (1938) states that this impact is due to the fact that the reproductive organs are the ones most likely to be affected by the low temperature. Foerster \& Nakama (2002) found that T. basalis and T. podisi kept for 20 days at $15^{\circ} \mathrm{C}$ had their fecundity reduced by more than $80 \%$ and $95 \%$, respectively, and as reported for T. remus, parasitoids maintained at $5^{\circ} \mathrm{C}$ for three days had a significant reduction in fecundity (Gautam, 1986).

\section{Conclusions}

1. Pupae of T. basalis and T. podisi do not survive at $12^{\circ} \mathrm{C}$, independently of their developmental stage at the time of storage.

2. Adult longevity at $15^{\circ} \mathrm{C}$ is higher when the pupae are transferred to $15^{\circ} \mathrm{C}$ at the end of the pupal stage.

3. Females of Trissolcus basalis parasitize eggs of Euschistus heros at $25^{\circ} \mathrm{C}$ after remaining in hibernation at $15^{\circ} \mathrm{C}$ for 120-210 days; females of Telenomus podisi do not parasitize eggs after 180 days at $15^{\circ} \mathrm{C}$.

\section{Acknowledgements}

To CNPq, for financial support.

\section{References}

ANDERSON, J.F.; KAYA, H.K. Diapause induction by photoperiod and temperature in the elm spanworm egg parasitoid, Ooencyrtus 
sp. Annals of the Entomological Society of the America, v.67, p.845-849, 1974.

ANDERSON, J.F.; KAYA, H.K. Influence of temperature on diapause termination in Ooencyrtus ennomus, an elm spanworm ege parasitoid. Annals of the Entomological Society of America, v. 68 , p.671-672, 1975.

AUSTIN, A.D. The fecundity, development and host relationships of Ceratobaeus spp. (Hymenoptera: Scelionidae), parasites of spider eggs. Ecological Entomology, v.9, p.125-138, 1984.

BOIVIN, G. Overwintering strategies of egg parasitoids. In WAJNBERG, E.; HASSAN, S.A. (Ed.). Biological control with egg parasitoids. Oxon: CAB International, 1994. p.219-244.

CURL, G.D.; BURBUTIS, P.P. The mode of overwintering of Trichogramma nubilale Ertle and Davis. Environmenta Entomology, v.6, p.629-632, 1977.

DOETZER, A.K. Sobrevivência dos parasitóides de ovos de Trissolcus basalis (Wollaston) e Telenomus podisi Ashmea (Hymenoptera: Scelionidae) durante a entressafra da soja sua eficiência após estocagem em baixas temperaturas. 2003. 146p. Tese (Doutorado) - Universidade Federal do Paraná, Curitiba FLANDERS, S.E. The effect of cold storage on reproduction of parasitic Hymenoptera. Journal of Economic Entomology, v.31, p.633-634, 1938.

FOERSTER, L.A.; NAKAMA, P.A. Efeito da estocagem em baixa temperatura na capacidade reprodutiva e longevidade de Trissolcus basalis (Wollaston) e Telenomus podisi Ashmead (Hymenopter: Scelionidae). Neotropical Entomology, v.31, p.115-120, 2002.

GAUTAM, R.D. Effect of cold storage on the adult parasitoid Telenomus remus Nixon (Scelionidae: Hymenoptera) and the parasitized eggs of Spodoptera litura (Fabr.) (Noctuidae: Lepidoptera). Journal of Entomological Research, v.10, p.125131, 1986

JALALI, S.K.; SINGH, S.P. Differential response of four Trichogramma species to low temperatures for short-term storage. Entomophaga, v.37, p.159-165, 1992.

JAMES, D.G.; WARREN, G.N. Effect of temperature on development, survival, longevity and fecundity of Trissolcus oenone Dodd (Hymenoptera: Scelionidae). Journal of the Australian Entomological Society, v.30, p.303-306, 1991.

LACEY, L.A.; MILLAR, L · KIRK, A.A.; PERRING T.M. Effect of storage temperatures and duration on survival of eggs and nymphs of Bemisia argentifolii (Homoptera: Aleyrodidae) and pupae of the whitefly parasitoid Encarsia formosa (Hymenopera: Aphelinidae). Arthropod Biology, v.92, p.430-434, 1999.

LAING, J.E.; CORRIGAN, J.E. Diapause induction and postdiapause emergence in Trichogramma minutum Riley (Hymenoptera: Trichogrammatidae): the role of host species, temperature, and photoperiod. Canadian Entomologist, v.127, p.103-110, 1995. MANSINGH, A. Physiological classification of dormancies in insects. Canadian Entomologist, v.103, p.983-1009, 1971.

ORR, D.B.; BOETHEL; D.J.; JONES, W.A. Development and emergence of Telenomus chloropus and Trissolcus basalis (Hymenoptera: Scelionidae) at various temperatures and relative humidities. Annals of the Entomological Society of America, v.78, p.615-619, 1985.

STINNER, R.E.; RIDGWAY, R.L.; KINZER, R.E. Storage, manipulation of emergence, and estimation of numbers of Trichogramma pretiosum. Environmental Entomology, v.3, p.505507, 1974.

Received on December 30, 2003 and accepted on May 4, 2004 